Article

\title{
Towards Explaining Varying Degrees of Politicization of EU Trade Agreement Negotiations
}

\author{
Dirk De Bièvre ${ }^{1, *}$ and Arlo Poletti ${ }^{2}$ \\ ${ }^{1}$ Department of Political Science, University of Antwerp, 2000 Antwerpen, Belgium; E-Mail: dirk.debievre@uantwerpen.be \\ 2 Department of Sociology and Social Research, University of Trento, 38122 Trento, Italy; E-Mail: arlo.poletti@unitn.it \\ * Corresponding author
}

Submitted: 3 December 2019 | Accepted: 24 February 2020 | Published: 31 March 2020

\begin{abstract}
Over the last decade, European Union (EU) trade agreement negotiations in the form of the Transatlantic Trade and Investment Partnership (TTIP) and the Comprehensive Economic and Trade Agreement (CETA) with Canada have been strongly contested. By contrast, many other EU trade negotiations have sailed on with far less politicization, or barely any at all. In this contribution, we assess a series of plausible explanation for these very varying degrees of politicization across EU trade agreement negotiations - conceived of as the combination of polarization of opinions, salience given to them in public debate, and the expansion of the number of societal actors involved therein. Through a review of existing explanations, we show how each of these explanations faces a set of challenges. In the third section, we argue it is useful to conceive of these existing explanations as structural background conditions enabling agency on the part of interest group and civil society organizations. We therefore close by sketching how literature on the relationship between interest group mobilization and public opinion could inform further comparative research on trade policy negotiations, and on politicization of EU policy making in general.
\end{abstract}

\section{Keywords}

European Union; interest groups; mobilization; negotiations; politicization; public opinion; trade policy

\section{Issue}

This article is part of the issue "Politicization of EU Trade Policy across Time and Space" edited by Dirk De Bièvre (University of Antwerp, Belgium), Oriol Costa (Universitat Autònoma de Barcelona, Spain/IBEI, Spain), Leif Johan Eliasson (East Stroudsburg University, USA) and Patricia Garcia-Duran (University of Barcelona, Spain).

(C) 2020 by the authors; licensee Cogitatio (Lisbon, Portugal). This article is licensed under a Creative Commons Attribution 4.0 International License (CC BY).

\section{Introduction}

Over the last two decades, the European Union (EU) has conducted an external economic policy very much in line with that of other major trade powers by prioritizing bilateral trade agreements over multilateral trade opening within the World Trade Organization (WTO). This strategic shift to preferential trade agreements, economic partnership or association agreements has been motivated by various factors, including the decline of the WTO's ability to deliver negotiated trade liberalization and regulation (Poletti \& De Bièvre, 2016), the competition with other trading partners in emerging markets (Dür, 2007) and the growing integration of the EU's economy in global value chains (Eckhardt \& Poletti, 2016).

These EU trade agreement negotiations have generated significant domestic political turmoil, and observers and analysts have contended that EU trade policy has evolved into a highly politicized policy area (Laursen \& Roederer-Rynning, 2017; Young, 2017). Defined as an "increase in polarization of opinions, interests or values and the extent to which they are publicly advanced towards the process of policy formulation" (de Wilde, 2011, p. 260), or, more broadly, as "making collectively binding decisions a matter or an object of public discussion" (Zürn, 2014, p. 50), politicization has potentially far 
reaching consequences for trade policy making. As noted by Dür, Eckhardt, and Poletti (2019), politicization can systematically trigger more protectionist trade policy preferences and it can also make it harder to bargain over mutually beneficial trade agreements. The fully-fledged politicization of trade policymaking in the EU-among the world's largest economies and trading powers-could have large consequences for one of the key tools of EU foreign policymaking, but also for the world trading system at large, as this would come at a time in which the threat of large-scale protectionism re-emerging, inspired by populist ideology, looms over it.

At the same time, the great variation in degrees of politicization across trade agreements (as well as across EU member states) has left many observers, practitioners and analysts somewhat baffled. Whereas EU-US negotiations over a Transatlantic Trade and Investment Partnership (TTIP) and EU-Canada negotiations over the Comprehensive Economic and Trade Agreement (CETA) have been strongly contested, many other EU trade negotiations have sailed on with far less politicization, or barely any at all, leaving one to wonder as to the potential causes. Several existing, plausible explanations for these varying degrees of politicization across EU trade agreement negotiations however, provide very generic explanations that would lead one to expect that all trade agreements should have become politicized. In this contribution we therefore review these existing explanations and parse out whether and where each of these explanations runs into problems. In the third section, we argue it is useful to conceive of these existing explanations as structural background conditions enabling agency on the part of interest group and civil society organizations and sketch how literature on the relationship between interest group mobilization and public opinion could inform further comparative research on trade policy negotiations, and on politicization of EU policy making in general.

\section{The Riddle: Varying Degrees of Politicization in EU Trade Policy}

We start by qualifying the proposition that EU trade policy is now highly politicized. In order to do so, we first draw a sketch of what a highly politicized trade negotiation would look like and assess how different EU trade agreement negotiations fare relative to such an operational definition. While there are different understandings of politicization in EU governance, there is growing consensus on the conceptualization proposed by De Wilde, Leupold, and Schmidtke (2016), which conceives of it as a three-dimensional process involving increasing salience, polarization of opinion and the expansion of actors and audiences involved in EU issues (see also De Bruycker, 2017). The 'salience' dimension captures the importance attributed to the EU and European integration and it is usually measured empirically by looking at the number of newspaper articles reporting on European governance or how 'aware' or 'worried' citi- zens are of the EU institutions, politics, and policies. The 'polarization' dimension gauges the emergence of a polarised scenario with diametrically opposed coalitions of societal groups at extreme positions with neutral voices having been crowded out, which is usually operationalized as polarization of a polity's party system or as disagreement about European governance in public opinion surveys. Finally, the 'actor and audience expansion' dimension captures the growing number of citizens and collective actors who dedicate resources in the form of time and money to follow and engage with EU governance. This can be grasped empirically by the expansion of actors making it to the news or that are active online and via social media.

This conceptualization suggests that the discussion about the politicization of EU trade policy cannot be confined to an exclusive focus on the traditional political conflicts that have always, although with different intensities, underlined the making of EU trade policy. As in other political systems, trade agreement negotiations have always sparked significant political conflicts in the EU. Traditionally, these conflicts have pit two sets of opposing concentrated trade-related interests against each other: export-oriented sectors wishing to see better access to foreign markets and import-competing sectors wishing to reduce exposure to foreign competition domestically (De Bièvre \& Dür, 2005; Dür, 2008). In the last two decades, these two types of actors have been joined by a third type, EU import-dependent firms, i.e., firms relying on the income generated by the imported intermediate or final goods, presenting themselves as strong advocates of trade liberalization as a result of the growing integration of the EU's economy in global value chains (Eckhardt \& Poletti, 2016; see also Baccini, Pinto, \& Weymouth, 2017). The intensity of conflict between these trade-related organized interests has on occasion been very high. The vociferous opposition of some EU members states' farmers in the Uruguay round or the car manufacturing sector in the EU-Korea negotiations are but two obvious examples of the potential of these trade-related interests to raise the intensity of political conflict underlying trade policy and to weigh on trade negotiations.

However, the presence of intense political conflicts between organized societal groups representing concentrated trade-related interests alone does not suffice to qualify a particular negotiation as politicized. The recent contribution by Meunier and Czesana (2019) on the politicization of EU trade policy acknowledges this important point, adding the key dimension of public salience to the picture. However, as the conceptual discussion developed above suggests, an exclusive focus on the dimension salience alone risks overlooking other important dimensions of politicization. We therefore go beyond the discussion by Meunier and Czesana (2019) and consider EU trade agreement negotiations as politicized when, in addition to evolving into issues that the general public is aware of and cares about (saliency), they also contribute 
to making trade policy an issue that polarizes political debates and opinions (polarization), and trigger the political mobilization of a wide array of political actors beyond the relatively closed circle of trade policy officials and groups representing trade-related interests such as NGOs and various kinds of citizen organizations (actor expansion).

With this conceptual yardstick in mind, it turns out that recent EU trade agreement negotiations differ very considerably in the degree to which they were politicized. In this contribution, we focus mainly on variation in degrees of politicization across the different bilateral or interregional trade negotiations that the EU has initiated. Although we do touch upon it here and there, we do not put the important question of how politicization of trade policy varies across EU member states centre stage here. This is an important line of inquiry, especially in light of an economistic domestic compensation hypothesis. This theoretical expectation would have it that the anti-globalization backlash should be largest in political systems that do not sufficiently compensate economic losers of liberalization (Sapir, 2001, 2006). Yet, politicization was highest in coordinated market economies with a strong welfare state, like Germany and Austria, low in Scandinavian welfare states, whereas it was also very low in many southern and eastern European countries, which actively kept supporting the negotiations (Young, 2017, pp. 71-74).

Moreover, we rely on existing operationalizations of degrees of politicization (see Steiner, 2018; Young, 2017) and do not expand on the desirability of a further systematic and fine-grained empirical estimate of how these negotiations fare with regards to each of conceptual dimension of politicization. Instead, we put our focus on how this wide variation in degrees of politicization could be explained. Several sources are now in wide agreement that actually only a minority of these negotiations generated a high degree of politicization (for instance Steiner, 2018; Young, 2017). Some of the EU's bilateral trade agreements, and some of its ongoing bilateral negotiations, did indeed generate unprecedented domestic political turmoil in the course of the past decade, especially the TTIP negotiations with the US-now aborted-and the negotiation and conclusion of the Canada-EU CETA. As widely documented, TTIP and also CETA quickly evolved into salient negotiations for the general public and mustered a wave of political contestation by a wide array of civil society groups, ultimately contributing to polarizing party competition and individual opinions (De Bièvre, 2018; De Bièvre \& Poletti, 2016; De Ville \& Siles-Brügge, 2015, 2016; Dür, 2018; Gheyle, 2019; Jungherr, Mader, Schoen, \& Wuttke, 2018; Kanthak \& Spies, 2018; Laursen \& Roederer-Rynning, 2017; Meunier \& Czesana, 2019; Steiner, 2018; Young, 2016, 2017, 2019).

Other EU bilateral negotiations and agreements, however, have taken place in the absence of public uproar, have barely led to a polarised distribution of opinions, and have not been the subject of attention from organized societal actors, the media, or the general pub- lic. These include the ongoing and finished negotiations with developing countries such as Vietnam, Thailand, and Malaysia, with advanced industrial and services competitors such as Japan, Singapore, and South Korea, or the negotiations for an investment-only agreement with an economic giant such as China. These negotiations did of course elicit opposition from traditional trade-related interests fearing the potential costs of liberalizing trade with these countries, like the European car industry in the case of the EU-South Korea trade agreement (Elsig \& Dupont, 2012; Gstöhl \& De Bièvre, 2018, pp. 93-107; Siles-Brügge, 2011), or the meat industry being up in arms about the expansion of Brazilian and Argentinian beef quota in the draft EU-Mercosur agreement.

Somewhat in between these two extremes, other negotiations did trigger actor expansion in the form of political opposition from organized societal groups other than import-competing groups, particularly by Civil Society Organizations (CSOs). These include the comprehensive trade agreement recently reached with Mercosur, which after approximately two decades in the doldrums moved into the public limelight late 2019, the Economic Partnership Agreement negotiations with former European colonies in the African, Pacific, and Caribbean region, most of which have failed to realize, with the notable exception of the agreement with the CARIFORUM region, and, to a lesser extent, the trade agreements signed with the Andean Community and Central American countries (Poletti \& Sicurelli, 2018). As the hot domestic political debate preceding the approval of the ratification of the EU-Ukraine association agreement in 2017 in the Netherlands shows, other intermediate cases included EU trade agreements that may have contributed to polarizing political debates in a small subset of member states, yet neither became salient for the general European public, nor elicited significant actor expansion across the EU as a whole.

This skewed distribution of politicization is by no means an exclusive feature of the politics of EU trade agreement negotiations. The political dynamics underlying the EU participation in multilateral trade negotiations, the administration of EU unilateral trade policy measures, and EU responses to dispute settlement procedures at the WTO, display similarly diverse patterns of politicization. The vocal street protests surrounding negotiations for the launch of the so-called Millennium Round of WTO negotiations in Seattle stand in contrast to the relative quiet with which other major multilateral trade rounds such as the Tokyo or Kennedy round have been negotiated in the past or the launch of the Doha Development Agenda (Poletti \& De Bièvre, 2016). The large scale political protests triggered by the US-initiated WTO disputes against EU bans on imports of genetically modified crops or hormone-treated beef also stand in contrast with the little noise elicited by other equally, if not more, economically important trade disputes (Poletti \& De Bièvre, 2014). This overview (summarized succinctly in Table 1) suggests that the puzzle at hand con- 
sists of explaining the varying degrees of politicization, rather than politicization of EU trade policy in general.

\section{Some Plausible (Necessary but not Sufficient) Conditions for Politicization}

A whole range of arguments about EU trade policy politicization have been advanced to account for politicization across EU trade agreement negotiations. The recent contribution by Meunier and Czesana (2019) systematizes this literature by evoking explanations for variation in salience of EU trade negotiations. Besides also taking polarization and actor expansion into account, in addition to salience, we draw and expand on this contribution in two ways. First, we make use of the overview of (non-)cases of politicization to conduct a brief plausibility probe of some of the most prominent explanations for this phenomenon. In doing so, we pay particular attention to specifying whether the considered explanatory factors represent necessary and/or sufficient conditions for the politicization of EU trade agreement negotiations. In this section, we therefore conduct a tentative and speculative probe of the explanatory power of existing arguments, and assess whether these factors unfold their explanatory force only in conjunction with other causes or suffice in and of themselves to produce politicization. We do so to lay the ground for how these can be usefully conceived as structural background conditions and allow one to bring agency back into the equation in Section 4.

\subsection{Variation in European and National Parliamentary Control over EU Trade Policy}

One plausible argument for the politicization of EU trade negotiations points to the effects generated by the in- creasing control over EU trade policy by the European Parliament (EP) introduced with the institutional reform of the Treaty of Lisbon of 2009. This mandated that EU trade agreements be ratified by a simple majority of members of the EP, turning this institution into a formal veto player in the policy process (Woolcock, 2010). EU trade agreement negotiations characterized by a high degree of politicization have taken place in the post-Treaty of Lisbon period, i.e., TTIP and CETA negotiations. While salience of EU trade agreements went up, polarization of opinions within the EP did not align along left-right lines, but cut right through some its most central parties. While the extreme left and Green faction was united in opposing EU trade negotiations, the European People's Party, and especially the Social-Democratic EP faction often found themselves split down the middle on the line to take on some of the most politicized EU external trade agreement negotiations (De Bièvre, 2018).

Others have claimed that also national parliaments have started to play a more important role than in the past in this policy process (e.g., Jančić, 2017; RoedererRynning \& Kallestrup, 2017). It is true that national governmental coalitions have demanded important recent bilateral trade agreements to be considered 'mixed' (i.e., both EU and member state competence) and hence have to be presented for ratification according to the national constitutional requirements, most often including the approval of the national parliament (Devuyst, 2013, p. 312). However, only CETA and TTIP negotiations became the subject of a high degree of politicization in a number of national legislatures. And secondly, the insistence of EU member state legislatures to ratify all external EU trade policy agreements (whether multilateral WTO or bilateral) has been a decade-old constant of EU trade policy making (Gstöhl \& De Bièvre, 2018; Meunier, 2005). This de facto member state veto over crucial issues, can be

Table 1. Politicization across EU trade agreement negotiations.

\begin{tabular}{lllll}
\hline EU trade agreement negotiations with & Salience & Polarization & Actor expansion & Level of politicization \\
\hline US-TTIP & Yes & Yes & Yes & High \\
CA-CETA & Yes & Yes & Yes & High \\
Mercosur & No & No & Yes & Low first; medium later \\
Japan & No & No & No & Low \\
Singapore & No & No & No & Low \\
South Korea & No & No & No & Low \\
Ukraine & No & Yes & No & Medium \\
Vietnam & No & No & No & Low \\
Thailand & No & No & No & Low \\
Malaysia & No & No & No & Low to medium \\
CARIFORUM & No & No & Yes & Low to medium \\
Andean Community & No & No & Yes & Low \\
Central America & No & No & No & Low \\
China (Investment) & No & No & No &
\end{tabular}

Source: The attribution of level of politicization in the last column is based on the elaboration of Eurobarometer data by Steiner (2018) and Young (2017); but see also Roederer-Rynning \& Kallestrup (2017) for salience in parliamentary debates. The dichotomous categorisation of the agreements with regard to the three dimensions of salience, polarization, and actor expansion is our own, cross-validated with peers. 
the consequence of the expansion of the trade agenda into matters of regulation within the remit and competence of EU member states (Young \& Peterson, 2006), as well as of the deliberate strategy to include issues of socalled mixed EU and member state competence into the negotiation mandate so as to make national parliamentary approval mandatory (Meunier \& Roederer-Rynning, 2020). Parliamentary opportunities to voice and mobilize opposition towards trade agreements thus constitute important background conditions for politicization, yet, in and of themselves do not suffice to account for when political actors jump to action to capitalize on them.

\subsection{Depth and Comprehensiveness of Regulatory Commitments in Preferential Trade Agreements}

Another prominent explanation for the politicization of EU trade agreement negotiations focuses on the increased depth and comprehensiveness of regulatory commitments discussed in these negotiations (for a detailed operationalization of regulatory depth and comprehensiveness, see Pelkmans, 2017). More specifically, a number of analyses suggest that politicization should be traced back to this growing importance of regulatory issues within so-called "new generation trade agreements" (Laursen \& Roederer-Rynning, 2017; Young, 2017; Young \& Peterson, 2006). However, times are long gone that a trade agreement only included commitments to reduce or abolish custom tariffs on trade in goods. As far back as the conclusion of the Uruguay Round agreements and the creation of the WTO in 1995, all trade agreement negotiation agendas included regulatory commitments about opening up markets for services, access for public procurement markets, the respect of domestic regulations on health and safety, the protection of intellectual property, the respect for minimum labour standards, environmental protection, as well as human rights (Dür, Baccini, \& Elsig, 2014). For over 25 years now, researchers have kept on calling this 'new'...

Still, there would seem to be a compelling logic to this line of reasoning; the deeper and more comprehensive the commitments have become, the more politicization has occurred. Since regulatory issues touch on sensitive domestic, behind-the-border issues they are likely to trigger public suspicion of regulatory downgrading in the face of international competition, which in turn should elicit a high degree of politicization. Such reactions should therefore be seen as embedded in the cultural contexts and the values and identities of social actors (see e.g., Duina, 2019, for an application to food). However, both logic and empirical evidencepuzzlingly-show that great depth and comprehensiveness of trade agreements do not consistently lead to greater politicization, perpetuating the question of when these actors mobilise this background potential, and especially when they do not.

For one, regulatory cooperation does not need to translate into lower regulation in the EU. The opposite can be true, as trading partners may engage in regulatory upgrading and thus impose costly regulatory burdens onto others via trade agreements (Lechner, 2016; Poletti \& Sicurelli, 2012; Young, 2015). Moreover, the argument stands at odds with the empirical observation that trade agreements containing deep regulatory provisions similar to those in TTIP and CETA, such as the EU-Japan agreement, have not elicited large scale politicization (Suzuki, 2017). In the TTIP negotiations, EU policy makers actually tabled less deep and comprehensive proposals on trade in services than in EU-Japan negotiations by adopting a so-called positive list approach, specifying which services sectors they would open up to American competition (Pelkmans, 2017). By contrast, negotiators adopted a far more ambitious and deep type of commitment approach in the agreements with Canada and Japan by only writing a negative list of those services sectors which would be exempted from the general rule that all services sectors would be liberalized. Again, while it may be necessary for a trade agreement to be 'deep' to trigger politicization, depth alone clearly does not suffice.

\subsection{Relative Economic Size and (Perceptions of) Bargaining Power of the Trading Partner}

A third candidate for explaining when politicization occurs, is the economic size and bargaining power of the negotiating partner. The larger the market of the EU relative to its negotiating partner, the greater the costs partners might be willing to incur in order to gain access to it (Damro, 2012; Dür, 2010). This suggests that EU agreements with smaller trading partners should be less politicized than those with partners of a roughly equal economic size. This is so because economic asymmetries make sure that the EU negotiates out of a position of strength, minimizing the risk that it has to make concessions on sensitive regulatory issues. This argument is consistent with observed patterns of politicization in the TTIP negotiations, which many observed to be somewhat linked to EU member state perceptions of the US as a negotiating partner with more bargaining power than the EU (De Ville \& Siles-Brügge, 2015; Garcia-Duran Huet \& Eliasson, 2018).

However, the argument is somewhat inconsistent with the high degree of politicization that characterized the CETA negotiations, i.e., negotiations with a much smaller and thus supposedly weaker trading partner. It is also somewhat at odds with the total absence of any politicization of the EU-Japan negotiations, admittedly a smaller, but still a very large economic player in the global trading system. With respect to Canada, one might argue that contestation over TTIP negotiations and fear of inferior EU bargaining power relative to the US may well have spilled over into contestation over the by-then already concluded CETA negotiations. The CETA and TTIP negotiations were particularly linked through the controversial issue of investment protec- 
tion and investment arbitration, as opponents stated that large US-based multinationals would be able to sue EU governments through their Canadian subsidiaries in such investor courts. Conversely, this line of argumentation suggests that the negotiations with Japan should have elicited concerns of having to concede much on regulatory issues to a relatively powerful trading partner, fears that did not materialize. These arguments thus again suggest that the impact of relative economic power (a)symmetries between the EU and its trading partners probably also has to be seen in conjunction with other conditions.

\section{Bringing Agency Back In}

So far, we have zoomed in on three important conditions for politicization-institutional opportunities, regulatory depth and scope, and bargaining strength. Of course, there are other conceivable (pre)conditions for politicization that could and should be integrated into the comparative analysis of politicization of EU trade agreement negotiations (Meunier \& Czesana, 2019). For instance, the rise of the internet and social-media represents an important development enabling the amplification of political messages, thus potentially bearing on the dimensions of salience and actor expansion. Similarly, it is eminently plausible that the growing popular and/or populist concerns over the merits of globalization observed across many EU member states (as in other advanced democracies) represent background factors relating to important dimensions of politicization. Yet, defined in this broad fashion, these arguments make it problematic to derive hypotheses on variation in degrees of politicization across trade agreement negotiations. For one, in both cases it is not easy to disentangle to what extent they point to factors that are independent of, and therefore can explain, politicization from processes that are in fact part of politicization itself. For instance, the use of social media and growing party confrontations over trade policy issues are themselves potential manifestations of processes of polarization and actor expansion. In addition, both arguments consider long-term processes that can hardly be useful to account for why trade negotiations taking place largely simultaneously (or in a shorttime span) display such different levels of politicization. For these reasons, we have not explicitly assessed these factors in the previous section. At the same time, we suggest that some aspects of these two broad sets of arguments can be usefully qualified with a view to contributing the development of new potential agency-based explanations of the politicization of EU trade policy.

The elements conducive to politicization we have discussed so far neglect the role of agency. Our plausibility probe of these explanations suggests that these structural conditions need to be present for politicization to arise, yet do not suffice to produce it, neither alone nor in conjunction. The argument that agency is crucial to trigger politicization is not exactly earth-shattering and there is clear anecdotal evidence about its importance in triggering the politicization of some EU trade agreement negotiations. Yet, it begs the question of when, how and why agency kicks in.

For instance, the successful attempts by organized groups to instigate and mobilize indignation, distrust, and opposition in the general public over the content of the TTIP and CETA negotiations bear witness to the importance that interest groups purposefully act as instigators and triggers of politicization (Buonanno, 2017; De Bièvre, 2014, 2018; De Ville \& Siles-Brügge, 2015, 2016; Garcia-Duran Huet \& Eliasson, 2018; Siles-Brügge, 2017). It is well documented that civil society actors make deliberate strategic choices and concentrate their financial means to "manufacture discontent" (Bauer, 2016) by focussing on a limited set of issues amenable to mobilizing fear. These included the singling out of topics that were by no means new or were not even part of the EU negotiation agenda, yet were singled out as topics for mobilization against TTIP as well as CETA (Duina, 2019; Young, 2017). Generating uncertainty and fear about whether or not the EU ban on the import of hormone treated beef would be maintained and whether chlorinated chicken would come to replace antibiotics-treated EU chicken were thus singled out by those groups in order to bank on already present salience, and polarize opinions and further actor expansion. Most importantly and most successfully, of course, the CSO campaign against TTIP politicized the 'Trojan horse' of investment arbitration, although that institution has been in existence for decades, and was about to be reformed as well as Europeanised (see for an analysis of that politicization and authority shift, Herranz-Surrallés, 2020). Importantly however, such singling out of lightning rods to rally mobilization did not happen in reaction to other EU trade agreement negotiations.

We therefore need to keep a rigorously comparative perspective in order to move beyond these important anecdotal observations and develop arguments about the conditions under which we can expect agents to be successful in seizing the opportunities their environment offers them to trigger politicization. In our view, uncovering such agency dynamics in the politicization of EU trade negotiations requires embracing research into the twoway interaction between individual level attitudes and preferences and their aggregation into public opinion on the one hand, and their deliberate strategic mobilization and politicization by interest groups and civil society organizations on the other.

\subsection{From Public Opinion to Agency}

A first line of inquiry would thus focus on the causal arrow going from public opinion to interest group agency. A growing number of contributions to the interest group literature have carved out the conditions under which public opinion can shape the dynamics of interest group agency. Rasmussen, Carroll, and Lowery (2014) for in- 
stance show that interest groups participate more actively on issues in policy areas that are regarded as salient by the general public. Kollman (1998) and Hanegraaff, Beyers, and De Bruycker (2016) focus on interest groups' strategies and provide systematic evidence that public opinion stimulates outside lobbying, i.e., strategies that seek to raise the awareness of a broader audience by communicating political messages through various sorts of public media. Others have shown how public support for advocates' policy preferences crucially affects the latter's' chances of success (De Bruycker, 2017; Rasmussen, Mäder, \& Reher, 2018). More generally, Hanegraaff and Poletti (2019) show that interest groups deem the support of public opinion as crucial for their survival chances. These studies suggest the importance of investigating how individual-level preferences and public opinion contribute to enabling interest groups to act as agents of politicization in EU trade policy.

On this account, a number of studies have already shown how individual-level preferences can significantly account for politicization of TTIP. Jungherr et al. (2018) have argued that attitudes towards specific trade agreements, rather than towards free trade in general, can account for the lack of support towards TTIP among German citizens. They find that postures toward transatlantic cooperation, predispositions toward the role of interest groups in politics, as well as towards domestic market regulation, constitute important background conditions for the remarkable opposition towards TTIP among German citizens. Other studies also suggest that variation in levels of public opposition to TTIP across EU member states could be due to citizens' views of the treaty partners, like anti-Americanism - at least under the important condition that the salience of economic issues is relatively low (Jedinger \& Schön, 2018; Steiner, 2018). However, anti-Americanism alone does not seem to suffice to explain opposition to TTIP, since other EU member states with latent anti-Americanism, such as France, did not witness a similar drop in specific support for TTIP negotiations (Bauer, 2016; Meunier \& Roederer-Rynning, 2020; Young, 2017). The presence of particular predispositions within the general public is important in shaping politicization only insofar as it comes in conjunction with interest groups able and willing to capitalize on this potential and act as agents of politicization (see also Gheyle, 2020). Similarly, Zürn, Binder, and Ecker Ehrhardt (2012), have convincingly highlighted the potential nexus exists between authority transfers and politicization: Political authority migrating from the national to the international level can trigger resistance by societal groups when international institutions cannot build on sufficient stocks of legitimacy. This argument suggests that CSOs should be more capable to act as agents of politicization of trade agreements that reach deeply into practices of domestic governance when public awareness and scepticism of international institutions are widespread among the general public. Future research could benefit from conducting further comparative analyses of all, rather than only a subset of EU trade agreement negotiations and parse out under which structural conditions issues already latently salient among the general public facilitate various kinds of interest groups, particularly CSOs, in their attempts to politicize EU trade policy. It would thus be worthwhile to analyse comparatively the extent to which instances of interest group success in acting as agents of politicization of EU trade policy issues can be traced back to how public opinion facilitated these groups' ability to mobilize, attract resources, decide upon a particular lobbying strategy, and successfully exert pressure on policymakers.

\subsection{From Agency to Public Opinion}

A second line of research could focus on the opposite causal arrow, namely the mechanisms that connect interest groups to public opinion, as the salience of issues may often be endogenous to and an artefact of group mobilization. Existing literature shows interest groups can shape public opinion formation in two ways. First, interest groups can use various means and strategies to affect the public salience of policy issues (Dür \& Mateo, 2014, 2016; Flöthe \& Rasmussen, 2018; Hanegraaff et al., 2016). Engaging in various kinds of outside lobbying strategies, can be instrumental to raising public awareness about policy issues. Second, interest groups may also contribute to shaping public attitudes on issues they care about through the frames they convey or by affecting news content (Andsager, 2000; Dür, 2018). The extent to which interest groups can effectively trigger the politicization of a particular trade policy issue or a particular negotiation thus largely depends on their ability to stimulate the interest and attention of public opinion. Indeed, increasing public salience of issues can trigger a positive feedback effect, stimulating more groups to join the campaign and thus generating an attention cascade that ultimately makes the issue even more salient (Dür \& Mateo, 2014; Halpin, 2011).

These insights on interest groups' capacity to actively shape public opinion can be leveraged to increase our understanding of the dynamics in politicization of EU trade policy. A wide range of studies have highlighted the material and cultural conditions that affect the formation of individual-level preferences on trade policy. The first group of studies usually considers such preferences as a function of the individual-level welfare effects of trade policy choices (Colantone \& Stanig, 2018; Jensen, Quinn, \& Weymouth, 2015; Margalit, 2011), while the second focuses on the role and identity-based consideration and cultural factors (Mansfield \& Mutz, 2009, 2013; Schaffer \& Spilker, 2019). These studies thus contribute to identifying one important set of micro-foundations of trade policy formation (Kertzer \& Zeitzoff, 2017; Owen \& Walter, 2017). Yet, it is eminently plausible that interest group agency is a crucial factor in mediating how material and cultural consideration affect individual preferences and public opinion more broadly over trade policy. 
For instance, Eliasson and Garcia-Duran Huet (2019) and Garcia-Duran Huet and Eliasson (2018) stress the importance of rhetorical choices made by interest groups by showing how the choice of emotive frames by CSOs opposing TTIP succeeded in raising public opposition to the agreement. Dür (2018) similarly shows, through an experimental research design, that the frames conveyed by interest groups might well be important in shaping public opinion over TTIP.

In order to more comprehensively account for high as well as low degrees of politicization, this line of research could therefore be further expanded in two directions. For one, one could investigate how other factors might enable civil society organizations to raise public opinion awareness over trade policy issues. The capacity of CSOs to use emotive frames or to convey particular frames may well be conditional on other factors, such as previous successful experiences of contestation of trade negotiations by CSOs, the types of lobbying strategies they employ (e.g., inside vs outside lobbying, or the use of particular types of media), their organizational characteristics (e.g., national vs. transnational, their amount of resources), and the characteristic of population of interest groups within which they operate (e.g., its density, diversity, and volatility). Second, it would be good if future research would expand its empirical scope by explicitly considering cases in which interest group attempts to raise the saliency of a particular trade policy issue did not succeed, so as to try and fully uncover the dynamics of agency success as well as failure.

\section{Conclusion}

In this contribution, we have sought to advance the stateof-the-art on the explanation of different degrees of politicization of EU trade agreement negotiations during the last decade. First of all, we have shown and illustrated that research on this important topic can benefit from following the lead of the more generic research on politicization in the EU by conceiving of the phenomenon as consisting of the three dimensions of salience, opinion polarization and actor expansion. This conceptualization has the advantage of being broad, while simultaneously allowing for a precise empirical mapping of the variation at hand that can stimulate systematic in-depth comparative research. Second, we have reviewed three plausible and relatively common explanations for politicization of these negotiations, namely the alleged increase of parliamentary-both national and Europeanscrutiny and involvement in EU trade policy, the depth and scope of regulatory commitments in trade agreements, and the relative bargaining power, based on economic size, of trading partners. Although we show that these are eminently plausible at first sight, these explanations also face considerable difficulties to account for the presence as well as the absence of politicization in a lot of instances. While particular constellations of those factors may be more or less conducive to politicization, we have gone on to argue that these factors can be very usefully considered background conditions creating the opportunity structures within which agency and mobilization can unfold. To that end, we have shown how the existing literature on the mutual interaction between public opinion and interest groups can be mobilized to further advance research on the politicization of particular trade agreement negotiations. Given that the EU is currently in the process of initiating, negotiating, and ratifying a whole set of such agreements, acquiring more in depth insight into these dynamics will continue to be of great relevance, both from a purely epistemological and scientific point of view and for the practical benefit of creating reasonable expectations about the process of EU trade policy formation in years to come.

\section{Acknowledgments}

Previous versions of this research note were presented at a Workshop on Trade Politicization at IBEI Barcelona in July 2018, the ECPR General Conference in Hamburg in August 2018, a lunch seminar at the Department of Political Science of the University of Geneva in March 2019, and at the EU Studies Association (EUSA) Conference in Denver in May 2019. We thank Oriol Costa, Andreas Dür, Maria Garcia, Patricia Garcia-Duran, Johan Eliasson, Niels Gheyle, Scott Hamilton, Simon Hug, Ivo Krizic, Lisa Lechner, Sophie Meunier, Guri Rosen, Gabriel Siles-Brügge, Tanja Schweinberger, Frédéric Varone, and Alasdair Young for earlier comments and suggestions. We acknowledge research funding from the Research Fund of the University of Antwerp (BOF) and the Jean Monnet Network on EU-Canada relations, The EU and Canada in Dialogue (2017-2020), coordinated by Carleton University, Ottawa (reference number 587014EPP-1-2017-1).

\section{Conflict of Interests}

The authors declare no conflict of interests.

\section{References}

Andsager, J. L. (2000). How interest groups attempt to shape public opinion with competing news frames. Journalism \& Mass Communication Quarterly, 77(3), 577-592.

Baccini, L., Pinto, P. M., \& Weymouth, S. (2017). The distributional consequences of preferential trade liberalization: Firm-level evidence. International Organization, 71(2), 373-395.

Bauer, M. (2016). Manufacturing discontent: The rise to power of anti-TTIP groups (ECIPE Occasional Paper No. 02/2016). Brussels: European Centre for International Political Economy. Retrieved from https:// www.econstor.eu/handle/10419/174737

Buonanno, L. A. (2017). The new trade deals and the mobilisation of civil society organizations: Comparing EU 
and US responses. Journal of European Integration, 39(7), 795-809.

Colantone, I., \& Stanig, P. (2018). Global competition and Brexit. American Political Science Review, 112(2), 201-218.

Damro, C. (2012). Market power Europe. Journal of European Public Policy, 19(5), 682-699.

De Bièvre, D. (2014). A glass quite empty: Issue groups' influence in the global trade regime. Global Policy, 5(2), 222-228.

De Bièvre, D. (2018). The paradox of weakness in European trade policy: Contestation and resilience in CETA and TTIP negotiations. The International Spectator, 53(3), 70-85.

De Bièvre, D., \& Dür, A. (2005). Constituency interests and delegation in European and American trade policy. Comparative Political Studies, 38(10), 1271-1296.

De Bièvre, D., \& Poletti, A. (2016). Why the Transatlantic Trade and Investment Partnership is not (so) new, and why it is also not (so) bad. Journal of European Public Policy, 24(10), 1506-1521.

De Bruycker, I. (2017). Politicization and the public interest: When do the elites in Brussels address public interests in EU policy debates? European Union Politics, 18(4), 603-619.

De Ville, F., \& Siles-Brügge, G. (2015). TTIP: The truth about the Transatlantic Trade and Investment Partnership. Cambridge: Polity Press.

De Ville, F., \& Siles-Brügge, G. (2016). Why TTIP is a gamechanger and its critics have a point. Journal of European Public Policy, 24(10), 1491-1505.

Devuyst, Y. (2013). European Union law and practice in the negotiation and conclusion of international trade agreements. Journal of International Business \& Law, 12(2), 259-316.

de Wilde, P. (2011). No polity for old politics? A framework for analyzing the politicization of European integration. Journal of European Integration, 33(5), 559-575.

de Wilde, P., Leupold, A., \& Schmidtke, H. (2016). Introduction: The differentiated politicisation of European governance. West European Politics, 39(1), 3-22.

Duina, F. (2019). Why the excitement? Values, identities, and the politicization of EU trade policy with North America. Journal of European Public Policy, 26(12), 1866-1882.

Dür, A. (2007). EU trade policy as protection for exporters: The agreements with Mexico and Chile. JCMS: Journal of Common Market Studies, 45(4), 833-855.

Dür, A. (2008). Bringing economic interests back into the study of EU trade policy-making. The British Journal of Politics \& International Relations, 10(1), 27-45.

Dür, A. (2010). Protection for exporters: Power and discrimination in transatlantic trade relations, 1930-2010. Ithaca, NY, and London: Cornell University Press.

Dür, A. (2018). How interest groups influence public opin- ion: Arguments matter more than the sources. European Journal of Political Research, 58(2), 514-535.

Dür, A., Baccini, L., \& Elsig, M. (2014). The design of international trade agreements: Introducing a new dataset. The Review of International Organizations, 9(3), 353-375.

Dür, A., Eckhardt, J., \& Poletti, A. (2019). Global value chains, the anti-globalization backlash, and EU trade policy: A research agenda. Journal of European Public Policy. Advance online publication. https://doi.org/ 10.1080/13501763.2019.1619802

Dür, A., \& Mateo, G. (2014). Public opinion and interest group influence: How citizen groups derailed the anticounterfeiting trade agreement. Journal of European Public Policy, 21(8), 1199-1217.

Dür, A., \& Mateo, G. (2016). Insiders versus outsiders: Interest group politics in multilevel Europe. Oxford: Oxford University Press.

Eckhardt, J., \& Poletti, A. (2016). The politics of global value chains: Import-dependent firms and EU-Asia trade agreements. Journal of European Public Policy, 23(10), 1543-1562.

Eliasson, L. J., \& Garcia-Duran Huet, P. (2019). Civil society, rhetoric of resistance, and transatlantic trade. London: Palgrave Macmillan.

Elsig, M., \& Dupont, C. (2012). European Union meets South Korea: Bureaucratic interests, exporter discrimination and the negotiations of trade agreements. Journal of Common Market Studies, 50(3), 492-507.

Flöthe, L., \& Rasmussen, A. (2018). Public voices in the heavenly chorus? Group type bias and opinion representation. Journal of European Public Policy, 26(6), 824-842.

Garcia-Duran Huet, P., \& Eliasson, L. J. (2018). Supporters' responses to contested trade negotiations: The European commission's rhetoric on the Transatlantic Trade and Investment Partnership. Cambridge Review of International Affairs, 30(5/6), 489-506.

Gheyle, N. (2019). Trade policy with the lights on: The origins, dynamics, and consequences of the politicization of TTIP (Unpublished Doctoral dissertation). Ghent University, Ghent, Belgium.

Gheyle, N. (2020). Huddle up! Exploring domestic coalition formation dynamics in the differentiated politicization of TTIP. Politics and Governance, 8(1), 301-311.

Gstöhl, S., \& De Bièvre, D. (2018). The trade policy of the European Union. London: Red Globe Press, MacmilIan International Higher Education.

Halpin, D. (2011). Explaining policy bandwagons: Organized interest mobilization and cascades of attention. Governance, 24(2), 205-230.

Hanegraaff, M., Beyers, J., \& De Bruycker, I. (2016). Balancing inside and outside lobbying: The political strategies of lobbyists at global diplomatic conferences. European Journal of Political Research, 55(3), 568-588. 
Hanegraaff, M., \& Poletti, A. (2019). Public opinion and interest groups' concerns for organizational survival. European Political Science Review, 11(2), 125-143.

Herranz-Surrallés, A. (2020). Authority shifts' in global governance: Intersecting politicizations and the reform of investor-state arbitration. Politics and Governance, 8(1), 336-347.

Jančić, D. (2017). TTIP and legislative-executive relations in EU trade policy. West European Politics, 40(1), 202-221.

Jedinger, A., \& Schoen, A. (2018). Anti-Americanism and public attitudes toward transatlantic trade. German Politics, 27(3), 317-338.

Jensen, J. B., Quinn, D. P., \& Weymouth, S. (2015). The influence of firm global supply chains and foreign currency undervaluations on US trade disputes. International Organization, 69(4), 913-947.

Jungherr, A., Mader, M., Schoen, A., \& Wuttke, A. (2018). Context-driven attitude formation: The difference between supporting free trade in the abstract and supporting specific trade agreements. Review of International Political Economy, 25(2), 215-242.

Kanthak, L., \& Spies, D. C. (2018). Public support for European Union economic policies. European Union Politics, 19(1), 97-118.

Kertzer, J. D., \& Zeitzoff, T. (2017). A bottom-up theory of public opinion about foreign policy. American Journal of Political Science, 61(3), 543-558.

Kollman, K. (1998). Outside lobbying: Public opinion and interest group strategies. Princeton, NJ: Princeton University Press.

Laursen, F., \& Roederer-Rynning, C. (2017). Introduction: The new EU FTAs as contentious market regulation. Journal of European Integration, 39(7), 763-779.

Lechner, L. (2016). The domestic battle over the design of non-trade issues in preferential trade agreements. Review of International Political Economy, 23(5), 840-871.

Mansfield, E. D., \& Mutz, D. C. (2009). Support for free trade: Self-interest, sociotropic politics, and out-group anxiety. International Organization, 63(3), 425-457.

Mansfield, E. D., \& Mutz, D. C. (2013). US versus them: Mass attitudes toward offshore outsourcing. World Politics, 65(4), 571-608.

Margalit, Y. (2011). Costly jobs: Trade-related layoffs, government compensation, and voting in U.S. elections. American Political Science Review, 105(1), 166-188.

Meunier, S. (2005). Trading voices: The European Union in international commercial negotiations. Princeton, NJ: Princeton University Press.

Meunier, S., \& Czesana, R. (2019). From back rooms to the street? A research agenda for explaining variation in the public salience of trade policy-making in Europe. Journal of European Public Policy, 26(12), 1847-1865.

Meunier, S., \& Roederer-Rynning, C. (2020). Missing in action? France and the politicization of trade and in- vestment agreements. Politics and Governance, 8(1), 312-324.

Owen, E., \& Walter, S. (2017). Open economy politics and Brexit: Insights, puzzles, and ways forward. Review of International Political Economy, 24(2), 179-202.

Pelkmans, J. (2017). Business dimensions of EU's new FTAs. Journal of European Integration, 39(7), 781-794.

Poletti, A., \& De Bièvre, D. (2014). Political mobilization, veto players, and WTO litigation: Explaining European Union responses in trade disputes. Journal of European Public Policy, 21(8), 1181-1198.

Poletti, A., \& De Bièvre, D. (2016). Judicial politics and international cooperation: From disputes to deal making at the world trade organization. Colchester: ECPR Press.

Poletti, A., \& Sicurelli, D. (2012). The EU as promoter of environmental norms in the Doha round. West European Politics, 35(4), 911-932.

Poletti, A., \& Sicurelli, D. (2018). The political economy of normative trade power Europe. London: Palgrave Macmillan.

Rasmussen, A., Carroll, B. J., \& Lowery, D. (2014). Representatives of the public? Public opinion and interest group activity. European Journal of Political Research, 53(2), 250-268.

Rasmussen, A., Mäder, L. K., \& Reher, S. (2018). With a little help from the people? The role of public opinion in advocacy success. Comparative Political Studies, 51(2), 139-164.

Roederer-Rynning, C., \& Kallestrup, M. (2017). National parliaments and the new contentiousness of trade. Journal of European Integration, 39(7), 811-825.

Sapir, A. (2001). Who's afraid of globalization? Domestic adjustment in Europe and America. In R. B. Porter, P. Sauvé, A. Subramanian, \& A. B. Zampetti (Eds.), Efficiency, equity, and legitimacy: The multilateral trading at the millennium (pp. 179-204). Washington, DC: Brookings Institution.

Sapir, A. (2006). Globalization and the reform of European social models. JCMS: Journal of Common Market Studies, 44(2), 369-390.

Schaffer, L. M., \& Spilker, G. (2019). Self-interest versus sociotropic considerations: An information-based perspective to understanding individuals' trade preferences. Review of International Political Economy, 26(6), 1266-1292.

Siles-Brügge, G. (2011). Resisting protectionism after the crisis: Strategic economic discourse and the EU-Korea free trade agreement. New Political Economy, 16(5), 627-653.

Siles-Brügge, G. (2017). Transatlantic investor protection as a threat to democracy: The potency and limits of an emotive frame. Cambridge Review of International Affairs, 30(5/6), 464-488.

Steiner, N. D. (2018). Attitudes towards the Transatlantic Trade and Investment Partnership in the European Union: The treaty partner heuristic and issue atten- 
tion. European Union Politics, 19(2), 255-277.

Suzuki, H. (2017). The new politics of trade: EU-Japan. Journal of European Integration, 39(7), 875-889.

Woolcock, S. (2010). EU trade and investment policymaking after the Lisbon treaty. Intereconomics, 45(1), 22-25.

Young, A. R. (2015). The European Union as a global regulator? Context and comparison. Journal of European Public Policy, 22(9), 1233-1252.

Young, A. R. (2016). Not your parents' trade politics: The Transatlantic Trade and Investment Partnership negotiations. Review of International Political Economy, 23(3), 345-378.

Young, A. R. (2017). The new politics of trade: Lessons from TTIP. New York, NY: Agenda Publishing.

Young, A. R. (2019). Two wrongs make a right? The politicization of trade policy and European trade strategy. Journal of European Public Policy, 26(12), 1883-1899.

Young, A. R., \& Peterson, J. (2006). The EU and the new trade politics. Journal of European Public Policy, 13(6), 795-814.

Zürn, M. (2014). The politicization of world politics and its effects: Eight propositions. European Political Science Review, 6(1), 47-71.

Zürn, M., Binder, M., \& Ecker-Ehrhardt, M. (2012). International authority and its politicization. International Theory, 4(1), 69-106.

\section{About the Authors}

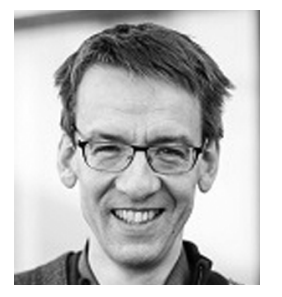

Dirk De Bièvre is Professor and Chair of the Department of Political Science at the University of Antwerp (Flanders, Belgium). He obtained his PhD in Social and Political Sciences from the European University Institute in Firenze, Italy, in 2002. Before moving to Antwerp, he was a Postdoctoral Research Fellow at the Max Planck Max Planck Institute for Research on Collective Goods in Bonn (2002-2003) and at the Mannheim Centre for European Social Research (2003-2006).

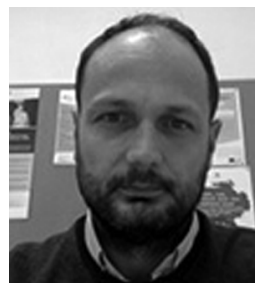

Arlo Poletti is an Associate Professor of International Political Economy at the Department of Sociology and Social Research of the University of Trento. His research focuses on the political processes that underlie, and are engendered by, international trade, international regulation, and transnational lobbying. 